\title{
Level of Adoption and Factor Affecting the Level of Adoption of Sustainable Soil Management Practices in Ramechhhap District, Nepal
}

\author{
Bikal Koirala $^{1,}$, , Jay Prakash Dutta ${ }^{1}$, Shiva Chandra Dhakal ${ }^{1}$, Krishna Kumar Pant ${ }^{2}$ \\ ${ }^{1}$ Department of Agricultural Economics, Institute of Agriculture and Animal Sciences, Rampur, Chitwan, Nepal \\ ${ }^{2}$ Department of Environmental Science, Institute of Agriculture and Animal Sciences, Rampur, Chitwan, Nepal
}

Emai address:

bikal.koirala@gmail.com (B. Koirala)

\section{To cite this article:}

Bikal Koirala, Jay Prakash Dutta, Shiva Chandra Dhakal, Krishna Kumar Pant. Level of Adoption and Factor Affecting the Level of Adoption Sustainable Soil Management Practices in Ramechhap District, Nepal. American Journal of Agriculture and Forestry.

Vol. 3, No. 2, 2015, pp. 21-25. doi: 10.11648/j.ajaf.20150302.12

\begin{abstract}
This study investigated the level of adoption and factor affecting the level of adoption of sustainable soil management practices. This research was based on the primary data that was collected in 2012 at Chisapani, Nagdaha and Kathjor VDCs of Ramechhap district of Nepal to analyze the level of adoption and factor affecting the level of adoption of sustainable soil management practices. Pre-tested semi structured interview schedule were used to collect the primary data from 120 farmers, 40 farmers from each VDC by applying simple random sampling technique. The major sustainable soil management practices adopted were found to be improved farm yard manure, improved cattle urine, inclusion of the vegetable and legume in the farming system and use of the bio-pesticide. The level of technology adoption was found to be $79.55 \%$ and this shows that the level of adoption was high. The higher level of adoption was due to increase in the production and productivity of the crops and improvement in soil fertility. While considering about the factor affecting the adoption of sustainable soil management practices, the study showed that the five variables namely training, credit, income, livestock standard unit and experience were significantly affecting for higher level of adoption. A unit increase in training, credit, livestock standard unit and experience would increase the probability of level of adoption by $3.48 \%, 0.83 \%, 0.45 \%$ and $1.1 \%$ respectively and a hundred rupees increase in income would increase the probability of level of adoption by $0.0819 \%$.
\end{abstract}

Keywords: Adoption, Production, Technology, Significantly, Sustainable Soil Management

\section{Introduction}

Nepal is an agricultural country with $65.6 \%$ of economically active population has agriculture as the major occupation (CBS, 2013). The supply of chemical fertilizer from Agricultural Input Company Limited rises to 10328.83 Metric ton in year 2009/10 as compared to 7133 metric ton in year 2008/09 and 142 metric ton of chemical pesticide in year 2011/12. The quantity was increase very highly in year 2010/11 which reached to 110013 metric ton (MoAD, 2012). This reflects the excessive use of fertilizer and its bad impact on soil health. The farmers obtains higher yield but do not replenish the harvested nutrients. This results in degradation of soil (karki and Dacayo, 1990). There is poor management (fertilizer, pesticides, irrigation etc) of soil as per its requirements which seriously have shown the problem of sustainability. Hence in the Nepalese context nutrient depletion and soil management for optimal crop production is major concern on soil sustainability. The haphazard use of chemical fertilizer and pesticide had resulted in unsustainability of soil and had toxic effect to human beings and animals. Nevertheless large amount of money is being spent on purchasing chemical fertilizers and pesticides from other countries .So adoption of sustainable agriculture is utmost necessary in Nepalese field. Sustainable agriculture system is that agricultural system which is capable of maintaining the productivity and usefulness to society for generations to generations (USDA, 1990). This system has some salient features such as resource conservation, socially just and supportive, commercially competitive and environmentally sounds. 


\section{Materials and Methods}

\subsection{Study Area and Sample Size}

Three VDCs of Ramechhap district namely Chisapani, Nagdaha and Kathjor were purposively selected to study the impact of SSM practices. Altogether 120 farmers adopting sustainable soil management practices were taken, 40 from each VDC using simple random sampling technique. The field survey was conducted in June, 2012. A co-ordination schema was developed and semi-structured interview schedule was prepared containing both closed and openended questions. Observations in the farmer's field were done, focus group discussion was conducted and key informant survey was carried out. The final analysis was done by using computer software Statistical Package for Social Sciences (SPSS), Microsoft Excel and STATA.

\subsection{Methodological Approach of Impact Evaluation}

Before after approach was used for the impact study of sustainable soil management practice. For the impact assessment pair $t$ test was used to test the impact of adoption of these practices on area and production of the different crops.

\subsection{Level of Technology Adoption}

First of all adoption score was calculated by doing sum of assigned points to the respondents. The level of technology adoption was calculated by using following formula

$$
\text { Level of technology adoption }=\frac{\text { Total score obtained by farmer }}{\text { Maximum possible score }} \times 100
$$

\subsection{Logit Regression Model}

Binary logit regression model was applied for analyzing the factors affecting the level of adoption of sustainable soil management practices which can be expressed as:

$\mathrm{Y}_{\mathrm{i}}=\mathrm{f}\left(\beta_{\mathrm{i}}, \mathrm{X}_{\mathrm{i}}\right)=\mathrm{f}($ Age, Economically active members, Education, Training, Farm size, Experience, Annual household income, credit, Livestock standard unit, gender )

The logit transformation can be expressed as: (Gujrati, 2003).

$\mathrm{L}_{\mathrm{i}}=\ln \left[\mathrm{p}_{\mathrm{i}} / 1-\mathrm{p}_{\mathrm{i}}\right]=\mathrm{Zi}=\alpha+\Sigma \beta_{\mathrm{i}} \mathrm{X}_{\mathrm{i}}+\varepsilon_{\mathrm{i}}$ where, $\mathrm{X}_{\mathrm{i}}=$ explanatory variables, $\beta_{\mathrm{i}}=$ parameters to be estimated , $\varepsilon_{\mathrm{i}}=$ error term

$\mathrm{Li}=\operatorname{logit}$ and $\left[\mathrm{p}_{\mathrm{i}} / 1-\mathrm{p}_{\mathrm{i}}\right]=$ Odd ratios

\section{Result and Discussion}

\subsection{Sustainable Soil Management Practices Adopted by} Farmers

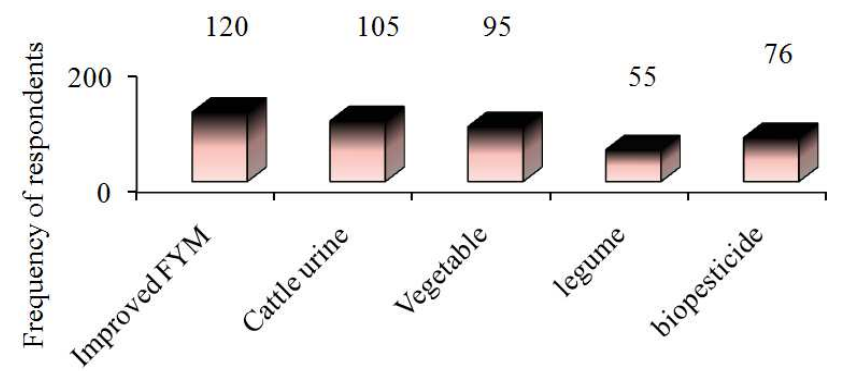

Types of practices

Figure 1. Frequency of different SSM techniques of used by farmers in study area (2012).

For the purpose of determining the techniques adopted by farmers focus group discussion was done. Mainly, five types of techniques were found that were used by farmers. During primary data collection it was found that one farmer had adopted one or more practices. They were improved farm yard manure, cattle urine, inclusion of vegetable in cropping system use of bio pesticide and inclusion of legumes in cropping pattern. Improved farm yard manure and improved cattle urine technique has resulted the less nitrogen loss. Similarly, inclusion of legume had helped in the reduced dose of nitrogen fertilizer to the soil due to the storage of nitrogen in the soil by the nitrogen fixing bacteria. Use of the bio pesticide had used in order to make the food organic. It was shown in Figure 1.

\subsection{Impact of Sustainable Soil Management Practices on Area and Production of Different Crops}

The impact of sustainable soil management practices on area and production of different crops was also studied using before after approach and pair t test was used for analysis. There was increase in production of rice and maize because they were main staple food in the study area. There was decrease in area and production of finger millet and wheat. This was due to farmers are oriented in vegetable farming and legumes, where previously finger millet and wheat were used to be grown and less attraction mainly towards finger millet. Farmers who used majority of finger millet for preparation of wine had now decreased in the preparation of wine and are used it consumption purpose, so the decrease in finger millet area and production and has not much effect. In gist the increase in production was due to increase in area (either by purchasing, or by sharing and lease hold), adoption of sustainable soil management practices and due to reason of increasing of income particularly by selling vegetables. Due to increase in production the level adoption of these practices is high. Pretty and Hine in 2001 also stated that adoption of sustainable agricultural practices had increased the yield by $50-100 \%$ for rain-fed crops. They also stated that by adopting sustainable agriculture by 12,500 households of Ethopia, there is increased in $60 \%$ yields. Similarly in a review of 286 projects in 57 countries the agricultural productivity was increased by $79 \%$ by means of sustainable agriculture or resource conserving agriculture (Pretty et.al, 2006). The area below was in ropani (Table 1) and the production was in kilogram (Table 2). 
Table 1. Impact of sustainable soil management practices on area of different crops in the study area (2012).

\begin{tabular}{llllll}
\hline & After & Before & Difference & t-value & Sig \\
\hline Rice area & 4.792 & 4.175 & 0.617 & $11.89^{* * *}$ & 0.000 \\
Maize area & 3.45 & 3.5 & -0.05 & -1.068 & 0.856 \\
wheat area & 1.254 & 1.479 & -0.225 & -5.742 & 0.500 \\
Finger millet & 3.02 & 3.362 & -0.342 & -4.687 & 0.487 \\
area & & 1.742 & 1.958 & $21.562^{* * *}$ & 0.000 \\
Vegetable area & 3.7 & 1.483 & 0.821 & $11.746^{* * *}$ & 0.000 \\
\hline
\end{tabular}

t-value obtained from paired t-test are significant different at $1 \%$ level of significance $(* * *)$

Table 2. Impact of sustainable soil management practices on production of different crops in the study area (2012).

\begin{tabular}{llllll}
\hline & After & Before & Difference & t-value & Sig \\
\hline $\begin{array}{l}\text { Rice production } \\
\text { maize }\end{array}$ & 521.5 & 361.625 & 159.875 & $16.727 * * *$ & 0.000 \\
$\begin{array}{l}\text { production } \\
\text { wheat } \\
\text { production }\end{array}$ & 290 & 202.458 & 87.542 & $17.47 * * *$ & 0.000 \\
$\begin{array}{l}\text { Finger millet } \\
\text { production }\end{array}$ & 102.25 & 105.95 & -3.7 & -1.153 & 0.932 \\
$\begin{array}{l}\text { Vegetable } \\
\text { production }\end{array}$ & 24.013 & 9.754 & 14.259 & $21.305 * * *$ & 0.000 \\
$\begin{array}{l}\text { Legume } \\
\text { production }\end{array}$ & 97.516 & 58.483 & 39.033 & $14.537 * * *$ & 0.000 \\
\hline
\end{tabular}

$\mathrm{t}$-value obtained from paired t-test are significant different at $1 \%$ level of significance $(* * *)$

\subsection{Level of Technology Adoption}

Majority of respondents was found higher level of adoption ( $>75 \%$ ) which was $75.38 \%$ followed by $24.17 \%$ of respondents doing $50-75 \%$ level of adoption of sustainable soil management practices which is shown in table no. 3 . The mean level of adoption was found to be 0.7955 with standard deviation of 0.0543 . Bhusal in 2012 also reported that level of adoption of cattle urine use technology (one of the sustainable soil management practices) was high. The higher level of adoption may be due to increase in production of different crops and improvement in soil fertility.

Table 3. Level of adoption of sustainable soil management practices in study area (2012).

\begin{tabular}{lllll}
\hline Level of adoption & Chisapani & Nagdaha & Kathjor & Total \\
\hline$<50 \%$ (Low) & $0(0.00)$ & $0(0.00)$ & $0(0.00)$ & $0(0.00)$ \\
$50 \%-75 \%$ (Medium) & $11(27.50)$ & $8(20.00)$ & $10(25.00)$ & $29(24.17)$ \\
$>75 \%$ (High) & $29(72.50)$ & $32(80)$ & $30(75.00)$ & $91(75.83)$ \\
Total & $40(100.00)$ & $40(100.00)$ & $40(100.00)$ & $120(100.00)$ \\
\hline
\end{tabular}

Figures in the parentheses indicates percentage

\subsection{Factor Affecting the Level of Technology Adoption}

Logit model was used for determining the factor that affect the level of adoption of SSM practices. In this age, economically active members, education, training, farm size, experience, income, credit and L.S.U are explanatory variables and level of adoption of practices is an explained variable. The adoption level was categorised into a binary response by the adoption level equal or more than $79 \%=1$ and 0 otherwise.

Logit regression analysis was done on 120 farmers, who were adopting SSM practices at different level. The wald test $\left(\mathrm{LR} \mathrm{chi}^{2}\right.$ ) for the model had good explanatory power at the 1\% level. The pseudo $\mathrm{R}^{2}$ was 0.7727 . In order to interpret the model, marginal effects were driven from regression coefficients. The interpretation is shown in table no. 4.

Logit regression analysis shows that out of ten explanatory variables taken, five variables were found to be statistically significant. These variables were training, experience, income, credit and livestock standard unit. It was found that age, economically active members, education, farm size and gender were found to be statistically insignificant. (shown in table 4)

Table 4. Factor affecting the level of SSM practice adoption in the study area (2012).

\begin{tabular}{|c|c|c|c|c|c|}
\hline Variables & Coefficients & $\mathbf{P}>|\mathbf{z}|$ & Standard error & $d y / d x^{b}$ & S.E $\mathbf{E}^{\mathrm{b}}$ \\
\hline Age & -0.0947 & 0.277 & 0.087 & -0.0002 & 0.0004 \\
\hline Economically active members & -0.282 & 0.76 & 0.924 & -0.0008 & 0.003 \\
\hline Education & 0.421 & 0.683 & 1.031 & 0.001 & 0.003 \\
\hline Training & $4.490^{* *}$ & 0.015 & 1.847 & 0.0348 & 0.048 \\
\hline farm size & -0.902 & 0.117 & 0.575 & -0.002 & 0.004 \\
\hline Experience & $2.150^{*}$ & 0.093 & 1.279 & 0.0116 & 0.022 \\
\hline Income & $0.0002^{* *}$ & 0.019 & 0.0001 & 0.00000819 & 0.000 \\
\hline Credit & $2.749^{* *}$ & 0.05 & 1.444 & 0.0083 & 0.014 \\
\hline LSU & $1.582^{*}$ & 0.094 & 0.946 & 0.0045 & 0.007 \\
\hline Gender & -0.889 & 0.383 & 1.019 & -0.002 & 0.004 \\
\hline Constant & -6.079 & 0.415 & 7.453 & & \\
\hline \multicolumn{6}{|l|}{ Summary statistics } \\
\hline Number of observation(N) & & \multicolumn{4}{|l|}{120} \\
\hline Log likelihood & & \multicolumn{4}{|c|}{-17.513984} \\
\hline $\operatorname{LR} \operatorname{chi}^{2}(10)$ & & \multicolumn{4}{|c|}{119.08} \\
\hline Pseudo $\mathrm{R}^{2}$ & & \multicolumn{4}{|c|}{0.7727} \\
\hline Goodness of fit test & & \multicolumn{4}{|c|}{ Pearson $\mathrm{Chi}^{2}=38.63$ Prob $>\mathrm{Chi}^{2}=0.9986$} \\
\hline
\end{tabular}

Training (dummy) was positively significant $(\mathrm{P}<0.05)$ to adopt the practices. The farmer may receive the training from both governmental and non-governmental organizations, the probability to adopt SSM practices increases by 3.48 percent. This might be due to increasing awareness to farmers, realization of advantage of practicing different practices and 
improving of skills. Bayard et al., 2006 also reported that training will positively influence the adoption level in soil management practices.

The variable experience was positively significant $(\mathrm{P}<0.1)$ to affect the level of adoption. A unit increase in the year of farming experience would increase the level of adoption by 1.1 percent. Rezvanfar et al. (2009) also reported that increase in experience increase the level of knowledge and increase the adoption of soil conservation practices. This might be due to experienced farmers have high level of knowledge skills in farming activities and well farm management.

Income was the important variable affecting the level of adoption. Annual income was found to be positively significant $(\mathrm{P}<0.05)$ and remaining other things constant, a hundred rupee increase in annual income would increase the level of adoption by 0.0819 percent. Higher the level of income they have high risk bearing capacity and there will be increase in investment. So, higher level of income will help to increase the adoption level and in their farm. Onweremadu and Matthews in 2007 also reported, increase in income will increase in adoption level of soil management practices.

The variable credit (dummy) was found to be positively significant $(\mathrm{P}<0.05)$. The farmers may have provision of credit from banking sector or cooperatives or other private conditions the probability to increase the level of adoption by 0.836 percent. This might be due to it open the area for investment, better farm management and decision. Jayasawal et. al. (2001) also reported that if there is provision of credit, than adoption of any technology would be high.

Livestock holding was one of the important variables in affecting the level of adoption and found to be positively significant $(\mathrm{P}<0.1)$. Keeping other things constant, each unit increase in livestock unit will increase the level of adoption by 0.45 percent. This was due to SSM practices are directly related with livestock. Romano et al. (2010) also reported that more the livestock there would be more adoption of technology. It was due to the reason that higher level of income and helping the adopters towards food security.

\section{Conclusion}

Agriculture is the major occupation in Ramechhap district. There is the subsistence oriented agriculture farming with maize, wheat, rice, finger millet and vegetables as the main crops. Before the adoption of practices the use of fertilizers and pesticides had adverse affect on soil resulting on different soil health problems. But after adopting different technique of sustainable soil management practices, there is the reduction of fertilizer and pesticide use and this has resulted in the increase in the production and productivity of the different crops. So the adoptions of these practices are high. This is due to increase in the production and less bad effect in the soil and the material required for these practices are locally available and cost effective. The different factors that affect the level of adoption are training, experience, income, credit and livestock standard unit.

\section{Acknowledgements}

I want to express my thanks to Dean, IAAS; Academic Dean, IAAS; Advisory committee, Department of Agricultural Economics, Colleagues, seniors, juniors, respondents of Ramechhap district for valuable and genuine information and my family.

\section{Refernces}

[1] Adhikari, J. (2000). Decisions for farm survival: Farm management strategies in the Mid-hills of Nepal. Adriot Publishers, New Delhi, India. 385p.

[2] Bayard, B., C.M. Jolly and D.A. Shannon. 2006. The adoption and management of soil conservation practices in Haiti: The case of rock walls. Agricultural Economics Review: 7(2) 2839.

[3] Bhusal, D. R.( 2012). Impact of cattle urine use technology on farm income of the vegetable growers of Dhading district, Nepal. Thesis submitted to Tribhuvan University, Nepal. 38p.

[4] CBS. (2013). Statistical pocket of Nepal. Government of Nepal, Central bureau of statistics, National Planning Commission Secretariat, Thapathali, Kathmandu.

[5] Karki, K.B. and J.B. Dacayo. (1990). Assessment of land degredation in southern Lalitpur of Nepal. Proceedings of $14^{\text {th }}$ Congress of International Society of Social Sciences, Tokyo, Japan. 38p.

[6] Jayasawal, M. L., B. N. Regmi, T. R. Noor, A Mcleod and J, Best. (2001). Using livestock to improve the livelihoods of landless and refugee affected livestock keepers in Bagladesh and Nepal. DFID. pp. 31-33.

[7] MoAD. (2012). Statistical information on Nepalese Agriculture. Ministry of Agriculture Development, Singh Durbar, Kathmandu, Nepal.

[8] Onweremadu, E.U. and E.C. Matthews. (2007). Adoption level and sources of soil management practices in low- input agriculture. Nature and Science 5(1) 39:45.

[9] Pretty, J. \& R. Hine. (2001). Reducing food poverty with sustainable agriculture: a summary of new evidence. UK: University of Essex Centre for Environment and Society. 24p.

[10] Pretty, J.N., A. D. Noble, D. Bossio, J. Dixon, R. E. Hine, F. W. T. Penning de Vries and J. I. L Morison. (2006). Resourceconserving agriculture increases yields in developing countries. Environmental Science and Technology (Policy Analysis) 40(4): 1114-1119.

[11] Rezvanfar, A., A. Samiee and E. Faham. (2009). Analyse of factor affecting adoption of sustainable soil conservation practices among wheat growers. World Applied Science of Journal 6(5): 644-651.

[12] Romano, D., E. Mane, M. D. Errico and L. Ellinovi. (2010). Livelihoods stragegies and household resilience to food insecurity: An empirical analusis to Kenya. European Report Development, Rome, Italy. pp. 15-25

[13] USDA. (1990). Debate on sustainability and development. USDA Bulletin, American Congress. 